\title{
Effect of Limb Muscle Power Training with Leaps on Athlete's Speed during the COVID-19 Pandemic
}

\author{
Yogi Mandala Putra ${ }^{1}$, Sugeng Purwanto ${ }^{2}$, Erick Burhaein ${ }^{3, *}$ \\ ${ }^{1}$ Master Program of Sports Science, Postgraduates Program, Universitas Negeri Yogyakarta, Yogyakarta 55281, Daerah Istimewa \\ Yogyakarta, Indonesia \\ ${ }^{2}$ Faculty of Sports Science, Universitas Negeri Yogyakarta, Yogyakarta 55281, Daerah Istimewa Yogyakarta, Indonesia \\ ${ }^{3}$ Doctoral Program of Sports Education, School Postgraduates Studies, Universitas Pendidikan Indonesia, Bandung, 40154, Jawa Barat, \\ Indonesia
}

Received February 5, 2021; Revised March 6, 2021; Accepted April 18, 2021

\section{Cite This Paper in the following Citation Styles}

(a): [1] Yogi Mandala Putra, Sugeng Purwanto, Erick Burhaein, "Effect of Limb Muscle Power Training with Leaps on Athlete's Speed during the COVID-19 Pandemic, "International Journal of Human Movement and Sports Sciences, Vol. 9 , No. 3, pp. 461 - 465, 2021. DOI: 10.13189/saj.2021.090310.

(b): Yogi Mandala Putra, Sugeng Purwanto, Erick Burhaein (2021). Effect of Limb Muscle Power Training with Leaps on Athlete's Speed during the COVID-19 Pandemic. International Journal of Human Movement and Sports Sciences, 9(3), 461 - 465. DOI: 10.13189/saj.2021.090310.

Copyright $\odot 2021$ by authors, all rights reserved. Authors agree that this article remains permanently open access under the terms of the Creative Commons Attribution License 4.0 International License

\begin{abstract}
This study aims to determine the effect of leg muscle power training with leaps on athlete's speed during the COVID-19 pandemic. The method in this study was a true experiment with pretest-posttest control group design. The total participants were 38 male athletes with an age range of $15-18$ years $(M=17.3$; SD: 1.26). Data analysis in this study is descriptive analysis and hypothesis testing. The results of the study are: 1) For the control group, the statement H0 "There is no effect of leg muscle power training with leaps on athlete's speed during the COVID-19 pandemic", is accepted. Then, there was a decrease in the mean of 0.23 or $1.78 \%$; 2) For the experimental group, H1 statement "There is effect of leg muscle power training with leaps on athlete's speed during the COVID-19 pandemic", is accepted. Then supported by an increase in the mean of 0.44 or $3.42 \%$. The conclusion is that there is an effect of leg muscle power training with leaps on athlete's speed during the COVID-19 pandemic. These findings may have implications, namely being a reference for trainers in developing training programs to increase leg muscle power with leaps that seem to be of significant effectiveness. For further researchers, it is hoped that they can modify other types of training and conduct research with a wider sample and population as well as add different variables so that the treatment given is to influence speed through treatment of leg muscle power.
\end{abstract}

Keywords Limb Muscle Power, Leap Training, Speed,
Athlete, COVID-19

\section{Introduction}

Speed is one of the biomotor components that an athlete must have in a sport that involves this element [1], [2]. Speed is defined as the amount of displacement made by an object in one unit of time [1], [3]. The running speed of an athlete is influenced by the leg muscle power. This is because power and speed are interrelated biomotor components. Athletes who have strong leg muscle power are able to run more optimally. The importance of training the leg muscle power of athletes in their respective clubs [2], [4].

The current COVID-19 pandemic is a global issue that has affected all aspects of the world, especially sports clubs [5]-[7]. There have been various kinds of training conditions since the pandemic in sports clubs, including: 1) Club and group training has been terminated in accordance with the government policy to prohibit crowd activities, and; 2) Club and group training cannot be continued despite strict health protocols, this is because the competition has not yet started and the sponsoring sponsors have withdrawn [8]-[11]. This condition certainly has to be addressed by athletes by practicing 
independently to maintain their physical abilities, especially the biomotor component of speed.

The importance of training leg power muscles to train speed during a pandemic is a real challenge that must be faced by athletes [12]-[14]. One of the trainings that can be done is the leaps training. Leaps training is a form of plyometric training to increase leg muscle power [15]. The implementation of the leaps training is a body position that is upright on one leg while the other leg is bent back, the posture of the hand bent at the side of the body. The legs are supporting jumping forward (on tiptoe) followed by the arms bent at the sides, the posture straight, the hands straight at the sides [1], [15].

Leaps training has an advantage especially during a pandemic like this time. The advantages of leap training include: 1) The ability to gain maximum power because the body weight is lifted with fast and continuous footsteps; 2) Can increase leg muscle power in running speed, and; 3) This training program is deemed suitable to be implemented independently during a pandemic [1], [2], [16].

Based on the existing problems, researchers are interested in conducting further studies on "The Effect of Limb Muscle Power Training with Leaps on Athlete's Speed during the COVID-19 Pandemic".

\section{Materials and Methods}

\subsection{Research Method}

This study used a quantitative research approach, then the design used was a true experimental research design with pretest-postest control group design [17], [18]. The research design is as shown in Table 1 as follows.

Table 1. True experiment pretest-postest control group design

\begin{tabular}{|c|c|c|c|c|}
\hline Treatment Group & $\mathrm{M}_{1}$ & $\mathrm{O}_{1}$ & $\mathrm{X}$ & $\mathrm{O}_{2}$ \\
\hline Control Group & $\mathrm{M}_{2}$ & $\mathrm{O}_{1}$ & $\mathrm{C}$ & $\mathrm{O}_{2}$ \\
\hline
\end{tabular}

Information:

$\mathrm{M}_{1}$ : The subjects of the treatment group with randomized

$\mathrm{M}_{2}$ : The subjects of the control group with randomized

$\mathrm{O}_{1}$ : Pretest

$\mathrm{X}$ : Providing treatment

$\mathrm{C}$ : Without treatment

$\mathrm{O}_{2}$ : Postest

\subsection{Participant}

Participants in this study used 38 male athletes with an age range of 15-18 years $(\mathrm{M}=17.3$; $\mathrm{SD}$ : 1.26). Participants were divided into two groups without being randomized, namely 19 athletes as the treatment group and 19 athletes as the control group. Participants will undergo a pretest, treatment, and posttest in the participants' home environment. The provisions for the venue can be at home (if it has a large enough hall) and an indoor field. All participants underwent treatment and testing with the guidance of researchers and followed health protocols during the pandemic.

\subsection{Instruments}

The research instrument used in this study was a 100 meters sprint speed test [19]. The subject ran a sprint from the start point to finish as far as 100 meters. Measurements using a stopwatch with standardized units of time. The test is carried out independently by the athlete assisted by a testor (preferably the closest fellow athlete from where he lives).

\subsection{Data Collection Technique}

The data collection techniques in this study were carried out by tests and measurements [18]. The data collection process begins with giving an explanation of the test implementation and warming up. Data were collected 2 times, namely at the beginning of the study (pretest) and the end of the study (posttest). Measurements (pretest \& postestt) using a stopwatch with standardized units of time for the speed athletes. The control group was left to do the exercises independently without any special treatment (treatment). For the treatment group, after doing the pretest they followed the process of training activities.

Athletes in the treatment group followed a leaps training program with theoretical standards in training including:

1. Explosive training load and speed [1], [20] ie 50-75\% intensity, sets of $4-6$, intervals of $2-5$ minutes, explosive/fast rhythm.

2. How to calculate the Maximum Repetition (RM) is that the athlete does 30 seconds of sprinting.

3. The frequency of training is carried out for 6 weeks with a frequency of training 3 times a week [1].

4. The increase in training load is calculated every 2 weeks by means of the RM test again.

5. The increase in load is individual

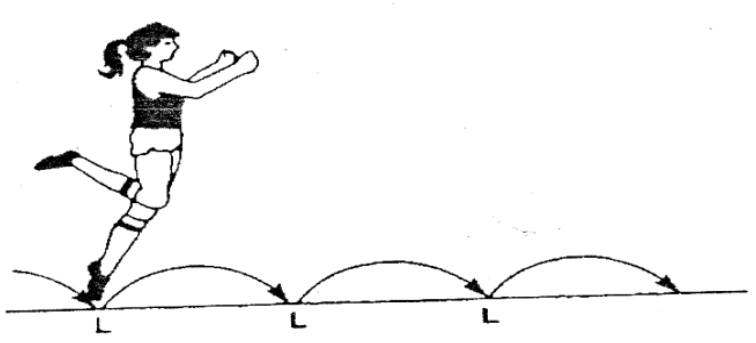

Figure 1. Technique steps in Leaps [15] 


\subsection{Data Analysis}

Data analysis in this study is descriptive analysis and hypothesis testing [18]. Descriptive analysis reveals descriptive data about the control and experimental groups. Then test the research hypothesis using the t-test. The research hypothesis is as follows:

Hypothesis 0 (H0): "There is no effect of leg muscle power training with leaps on athlete's speed during the COVID-19 pandemic".

Hypothesis 1 (H1): "There is an effect of leg muscle power training with leaps on athletes' speed during the COVID-19 pandemic".

\section{Results}

\subsection{Results of Descriptive Data of the Control Group Pretest and Posttest}

The results of the descriptive statistics for the pretest and posttest athlete's speed in the control group $(n=19)$ can be seen in table 2 .

Table 2. Statistics Descriptive speed of athlete of the control group athletes

\begin{tabular}{ccc}
\hline Statistik Deskriptif & Pretest & Postest \\
\hline Mean & 12.93 & 13.16 \\
\hline Median & 13.16 & 13.21 \\
\hline Mode & 11.29 & 11.67 \\
\hline Std. Deviation & 1.09 & 1.12 \\
\hline Minimum & 11.28 & 11.67 \\
\hline Maximum & 14.42 & 14.60 \\
\hline Difference in Mean (time) & \multicolumn{3}{c}{$(+) 0.23$} \\
\hline Percentage of Decrease (speed) & \multicolumn{3}{c}{$1.78 \%$} \\
\hline
\end{tabular}

The results of the description show that the pretest to posttest mean (time) from 12.93 increases to 13.16. This means that there is an increase in time 0.23 which means that the speed decreases $1.78 \%$. This means that when viewed from the comparison of the mean, the athlete's speed in the control group experienced a decrease (speed). Further hypothesis testing is needed to strengthen these findings.

\subsection{Results of the Experimental Group Pretest and Posttest Descriptive Data}

The results of the descriptive statistics for the pretest and posttest athlete's speed in the experimental group $(\mathrm{n}=$ 19) can be seen in table 3 .
Table 3. Descriptive statistics of the experimental group athlete's speed

\begin{tabular}{ccc}
\hline Statistik Deskriptif & Pretest & Postest \\
\hline Mean & $12 . .86$ & 12.42 \\
\hline Median & 12.48 & 12.34 \\
\hline Mode & 11.28 & 11.07 \\
\hline Std. Deviation & 0.99 & 0.98 \\
\hline Minimum & 11.28 & 11.07 \\
\hline Maximum & 11.42 & 14.28 \\
\hline Difference in Mean (time) & \multicolumn{3}{c}{ (-) 0.44} \\
\hline Percentage of Increase (speed) & $3.42 \%$ \\
\hline
\end{tabular}

The results of the description show that the mean pretest to posttest (time) from 12.86 decreased to 12.42 . This means that there was a decrease in time 0.44 which means that the speed increased by $3.42 \%$. This means that when viewed from the comparison of the mean, the athlete's speed in the experimental group experienced an increase (speed). Further hypothesis testing is needed to strengthen these findings.

\subsection{Hypothesis Testing}

The results of the t-test pretest and posttest of the control group as well as the experimental speed of the athletes are presented in table 4 . After the t-test results are known, it is followed by hypothesis testing of the control and experimental groups.

Table 4. Hypothesis testing of the control and experiment group athlete's speed

\begin{tabular}{cccc}
\hline Pretest - Posttest & t & df & Sig. (2-tailed) \\
\hline Control Group & 1,877 & 18 & 0.010 \\
\hline Experiment Group & 3.753 & 18 & 0.000 \\
\hline
\end{tabular}

Based on the calculation of pretest and posttest data in the control group on the the athlete's speed, the value of $p$ $=0.010$ was obtained, meaning that $\mathrm{p}>0.005$ so that $\mathrm{H} 0$ was accepted and H1 was rejected. So for the control group, the statement H0 "There is no effect of leg muscle power training with leaps on athlete's speed during the COVID-19 pandemic", is accepted.

Based on the calculation of pretest and posttest data in the experimental group on the athlete's speed, the value of $p=0.000$ is obtained, meaning that $p<0.005$, so H0 is rejected and $\mathrm{H} 1$ is accepted. So for the experimental group, $\mathrm{H} 0$ "There is no effect of leg muscle power training with leaps on athlete's speed during the COVID-19 pandemic", is Rejected. So, H1 statement "There is an effect of leg muscle power training with leaps on athlete's speed during the COVID-19 pandemic", is accepted. 


\section{Discussion}

Leaps training is a practice of jumping bounces on one leg performed repeatedly. With a strong and fast bouncing jump motion, the power elements of the lower muscles are maximally developed, so that adequate leg muscle power is formed [15].

Judging from its implementation, leaps training requires stronger and faster work of the leg muscles in order to be able to jump as high and as far as possible in a sustainable manner [21], [22]. Jumping on one leg is quite a strenuous movement, because the muscles in the leg are required to work to lift the body with one leg and land on one leg as well, so that when landing this leg holds the weight. Jumping with heavy loads and carried out quickly, the leg muscles develop.

With the development of strength and speed of the leg muscles, it will produce adequate leg muscle power [2], [23]. Both force and speed of movement are very important in the principles of plyometric training, especially leaps training. In many cases, the emphasis is on the speed at which a particular action can be performed. Judging from the leaps training movement, this movement resembles a jumping technique (take off), where in the leaps training it is done by jumping using one leg which is done strongly and quickly. Leaps training focuses on bouncing jumping movements that are carried out strongly and quickly, then the elements of the lower muscle power are maximally developed, so that adequate leg muscle power is formed which affects the increase in athlete's speed [1], [15].

The results of the study in the control group showed that the average pretest to posttest (time) from 12.93 increased to 13.16. This means that there was an increase in time of 0.23 , which means that the speed decreased by $1.78 \%$. This is in line with the acceptance of the hypothesis $\mathrm{H} 0$ that " There is no effect of leg muscle power training with leaps on athlete's speed during the COVID-19 pandemic". The results of the study in the treatment group showed that the average pretest to posttest (time) from 12.86 decreased to 12.42 . This means that there was an decrease in time 0.44 , which means that the speed increased by $3.42 \%$. This is in line with the acceptance of the hypothesis $\mathrm{H} 1$ that " There is an effect of leg muscle power training with leaps on athlete's speed during the COVID-19 pandemic".

A person who has high leg muscle power will easily develop his running speed, both in his reaction speed (at start), acceleration of motion (in the first few meters), basic velocity (as maximum speed) and on his stamina of speed (endurance of speed) when compared to someone who has low leg muscle power [1], [24]. For someone who has high leg muscle power, it will result in a higher stride frequency and a longer stride length when running when compared to someone who has a low stride frequency. This is very useful for producing the maximum running speed when running because running speed is the result of the frequency of steps and the length of the athlete's stride.

\section{Conclusions}

Based on the above conclusions, it can be seen that there is an effect of leg muscle power training with leaps on athlete's speed during the COVID-19 pandemic. These findings may have implications, namely being a reference for trainers in developing training programs to increase leg muscle power. The findings of this study can be used as a reference for increasing leg muscle power training with leaps that seem to be of significant effectiveness.

This research is not without limitations in its implementation. Limitations of the study include: 1) The researcher cannot control the athlete's activity outside of training which can affect the test results, such as body condition, psychological factors, and so on; and 2) The fluctuating government policies during the pandemic have a direct and indirect impact on athletes during treatment.

For further researchers, it is hoped that they can modify other types of training and conduct research with a wider sample and population as well as add different variables so that the treatment given is to influence speed through treatment of leg muscle power.

\section{Acknowledgments}

The author would like to thank all those who supported this research.

\section{Conflict of Interest}

All authors state that there is no conflict of interest in this study.

\section{REFERENCES}

[1] T. O. Bompa and C. Buzzichelli, Periodization Theory and Methodology of Training, Sixth. United States, 2019.

[2] E. Burhaein, B. K. Ibrahim, and R. Pavlovic, "The Relationship of Limb Muscle Power, Balance, and Coordination with Instep Shooting Ability: A Correlation Study in Under-18 Football Athletes," Int. J. Hum. Mov. Sport. Sci., vol. 8, no. 5, pp. 265-270, 2020. DOI: 10.13189/saj.2020.080515.

[3] B. Doyle, D. Browne, and D. Horan, "The relationship of aerobic endurance and linear speed on repeat sprint ability performance in female international footballers," Int. J. Hum. Mov. Sport. Sci., vol. 8, no. 4, pp. 147-153, 2020. DOI: $10.13189 /$ saj.2020.080407.

[4] E. Burhaein, B. Tarigan, and D. T. P. Phytanza, "The 
experience and understanding of the $\mathrm{K}-13$ curriculum implementation of Indonesian teachers of Adapted Physical Education (APE)," Int. Sport. Stud., vol. 42, no. e, pp. 29-42, 2020 .

[5] J. Woods et al., "The COVID-19 pandemic and physical activity," Sport. Med. Heal. Sci., vol. 2, no. 2, pp. 55-64, 2020.

[6] E. Burhaein, D. T. P. Phytanza, and N. Demirci, "The development and validation of a revised Friendship Activity Scale and Adjective Checklist for use in the Indonesian Unified Sports program," Int. Sport. Stud., vol. 42, no. e, pp. 18-28, 2020.

[7] E. Burhaein, "Pembelajaran dalam Pandemi COVID-19: Mengapa Pendidikan Jasmani Adaptif Penting untuk Siswa Disabilitas di Sekolah Luar Biasa," in Disrupsi Strategi Pembelajaran Olahraga: Serta Tantangan dalam Menghadapi New Normal selama masapandemi Covid-19, Tulungagung: Akademia Pustaka, 2020, pp. 187-196.

[8] C. Brom, J. Lukavsky, D. Greger, and T. Hannemann, "Mandatory Home Education during the COVID-19 Lockdown in the Czech Republic: A Rapid Survey of 1 st -9 th Graders' Parents," Front. Educ., vol. 5, no. 103, pp. 1-11, 2020.

[9] S. Ravalli and G. Musumeci, "Coronavirus Outbreak in Italy : Physiological Benefits of Home-Based Exercise During Pandemic," J. Funct. Morphol. Kinesiol., vol. 5, no. 31, pp. $1-6,2020$.

[10] J. Wu and P. Zha, "Preventive, Mitigating, and Treatment Strategies for COVID-19," SSRN, vol. 2020, no. February 25, pp. 1-38, 2020.

[11] E. Burhaein, "Bagaimana Pendidikan Jasmani Adaptif di Era New Normal," in Bunga Rampai Strategi, Proses, Evaluasi, dan Model Pembelajaran Pendidikan Jasmani, Olahraga, dan Kesehatan (PJOK) pada Era Pandemi Covid-19, Surabaya: UNESA University Press, 2020.

[12] R. Ardian, S. Suharjana, and E. Burhaein, "Effect of progressive and repetitive part methods against the accuracy of kicking in football extracurricular students," ScienceRise, vol. 1 , no. 7, pp. 40-44, 2019.

[13] I. A. D. Pramantik and E. Burhaein, "Disabilities Sports \& Health Science A Floor Time Approach to Improve
Learning Outcomes of the Body Roll to the Side in Adaptive Physical Education Learning: Classroom Action Research Study on Two Cerebral Palsy Students," Int. J. Disabil. Sport. Heal. Sci., vol. 2, no. 2, pp. 45-53, 2019.

[14] D. T. P. Phytanza and E. Burhaein, "Aquatic activities as play therapy children autism spectrum disorder," Int. J. Disabil. Sport. Heal. Sci., vol. 2, no. 2, pp. 64-71, 2019.

[15] G. A. Carr, Athetics for School. Jakarta: PT Raja Grafindo Persada, 2003.

[16] N. Subadrah and M. Malar, "Penggunaan Model Konstruktivisme Lima Fasa," J. Pendidik dan Pendidik., vol. 20, no. 1987 , pp. 21-41, 2005.

[17] D. T. P. Phytanza and E. Burhaein, "The Effects of Tenure, Teacher Certification, and Work Motivation on Special Needs Teacher Performance," Univers. J. Educ. Res., vol. 8, no. 9, pp. 4348-4356, 2020.

[18] J. R. Fraenkel, N. E. Wallen, and H. H. Hyun, How to design and evaluate research in education. New York: Mc Graw Hill, 2012

[19] Topend Sports, "Sprint or Speed Test," 2020. [Online]. Available: https://www.topendsports.com/testing/tests/sprint.htm. [Accessed: 20-Jan-2020].

[20] J. Nossek, General theory of training. Logos: Pan African Press, 1982.

[21] A. Cicchella, "Kinematics analysis of selected rhytmic gymnastic leaps," J. Hum. Sport Exerc., vol. 4, no. 1, pp. 40 47, 2009.

[22] E. Burhaein, "Aktivitas Permainan Tradisional Berbasis Neurosainslearning Sebagai Pendidikan Karakter Bagi Anak Tunalaras,” J. Sport. J. Penelit. Pembelajaran, vol. 3, no. 1, p. 55, 2017.

[23] E. Burhaein, "Aktivitas Fisik Olahraga untuk Pertumbuhan dan Perkembangan Siswa SD," Indones. J. Prim. Educ., vol. 1, no. 1, pp. 51-58, 2017.

[24] S. K. Powers and T. H. Edward, Exercise physiology theory and application to fitness and performance. New York: McGraw-Hill Education, 2007. 